\title{
Plant Growth Regulators and Mowing Height Affect Ball Roll and Quality of Creeping Bentgrass Putting Greens
}

\author{
Matthew J. Fagerness ${ }^{1}$, Fred H. Yelverton ${ }^{2}$, John Isgrigg, III ${ }^{3}$, and \\ Richard J. Cooper ${ }^{4}$ \\ Department of Crop Science, North Carolina State University, Raleigh, \\ NC 27695-7620
}

Additional index words. Agrostis palustris, Stimpmeter, ball roll, trinexapac-ethyl,
paclobutrazol

\begin{abstract}
Questions exist as to whether growth-inhibiting chemicals mimic the effects of reduced mowing heights on putting green ball roll. An experiment was initiated during Spring 1997 to investigate ball roll and visual quality parameters of putting greens maintained at 3.2, 4.0 , or $4.8 \mathrm{~mm}$ with plant growth regulator (PGR) treatments applied monthly over the course of 1 year. Additional experiments were conducted during Fall 1995 and 1996 and Spring 1996 to investigate diurnal PGR effects on ball roll. All experiments were conducted on pure stands of 'Penncross' creeping bentgrass (Agrostis palustris Huds). Treatments included trinexapac-ethyl and paclobutrazol, both inhibitors of gibberellin biosynthesis. In the one-year experiment, mowing height was inversely related to ball roll. However, compromises in turfgrass visual quality and shoot density in 'Penncross' turf mowed at $3.2 \mathrm{~mm}$ make this a questionable mowing height in areas with severe summer conditions. Ball roll during summer months was reduced by PGRs, suggesting that PGRs have little potential as alternatives to decreasing mowing height for increased ball roll. Paclobutrazol reduced turfgrass quality and shoot density during summer months, suggesting that it be used with caution. Other PGRs, particularly trinexapac-ethyl at $0.05 \mathrm{~kg} \cdot \mathrm{ha}^{-1}$ a.i., increased afternoon ball roll by as much as $5 \%$ to $10 \%$ in diurnal experiments. Use of PGRs on creeping bentgrass putting greens may therefore produce short-lived increases in ball roll with subtle to negative effects on bentgrass growth over more extended periods of time. Chemical names used: 4-(cyclopropyl- $\alpha$ hydroxymethylene)-3,5-dioxocyclohexane carboxylic acid ethylester (trinexapac-ethyl); $(+/-)-\left(R^{*}, R^{*}\right)-\beta-[(4-c h l o r o-p h e n y l) m e t h y l]-\alpha-(1,1$ dimethylethyl)-1H-1,2,4-triazole-1ethanol (paclobutrazol).
\end{abstract}

Creeping bentgrass is used worldwide on golf course putting greens and is often regarded as the best turfgrass species for this purpose. Desirable attributes of creeping bentgrass include excellent tolerance to low mowing, adaptation to temperate and transition zone climates, a stoloniferous growth habit that facilitates development of a dense putting surface, and good recuperative ability in response to traffic and environmental stress. The use of creeping bentgrass as a putting green surface has extended into the transition zone of the United States (Callahan,

\footnotetext{
Received for publication 26 Apr. 1999. Accepted for publication 21 Sept. 1999. This work was supported in part by O.M. Scotts and Sons Co., Marysville, Ohio, and the Turfgrass Council of North Carolina, Southern Pines, N.C. We thank Tom Garrett and Ron Gilmore for on-site support and Cavell Brownie in the Dept. of Statistics, North Carolina State Univ. for advice regarding statistical analyses. The cost of publishing this paper was defrayed in part by the payment of page charges. Under postal regulations, this paper therefore must be hereby marked advertisement solely to indicate this fact.

${ }^{1}$ Graduate Research Assistant. E-mail address: bigfinn@earthlink.net

${ }^{2}$ Associate Professor.

${ }^{3}$ Research Agronomist, Zeneca Corp., Des Moines, Iowa.

${ }^{4}$ Professor
}

1978). This has created management difficulties, as the species often has difficulty coping with high temperatures and humidity in these areas. Possible solutions to this problem include breeding of cultivars with superior heat and/or drought tolerance, increasing mowing heights (Mazur, 1986), supplementing irrigation situationally (e.g., syringing) and, perhaps, using plant growth regulators (PGRs).

Growth of shoots and roots of creeping bentgrass is maximal during spring and fall. Because most PGRs are applied to inhibit turfgrass growth, applications of these compounds to cool-season turfgrass species are also most common at these two times of the year (Johnson, 1989). The most frequently used PGRs on highly maintained turfgrasses function by inhibiting gibberellin (GA) biosynthesis, thus reducing cell division and elongation in foliar tissues. Examples of these types of PGRs are trinexapac-ethyl and paclobutrazol, which are absorbed by the foliage and roots, respectively, of turfgrass (Watschke and DiPaola, 1995). Paclobutrazol has stereoisomeric similarity to sterol-inhibiting fungicides and inhibits the ent-kaurene to ent-kaurenol step in the GA biosynthetic pathway, while trinexapac-ethyl inhibits the $3 \beta$-hydroxylation reaction that converts $\mathrm{GA}_{20}$ to $\mathrm{GA}_{1}$, the active form. The impact of PGR applications on creeping bentgrass during either suboptimum periods of growth or over extended periods of time has not been fully investigated.

While PGRs reduce shoot growth in many turfgrass species (Fagerness and Penner, 1998a, 1998b), the extent to which they affect growth and quality of putting green turf has only recently been investigated. Because putting greens are maintained at specific canopy heights more aggressively than are turfgrasses under any other type of management regime, detection of the potential effects of PGR applications might be difficult. Previous research with PGRs on creeping bentgrass putting greens has focused on delaying bermudagrass (Cynodon sp.) encroachment (Johnson and Carrow, 1989), suppression of annual bluegrass (Poa annua L. ssp. reptans) (Johnson and Murphy, 1996), and disease prevention (Burpee et al., 1996).

A practical way to assess putting green canopy height indirectly is by measurement of ball roll on the surface. Ball roll on creeping bentgrass putting greens is significantly affected by time of year, but cultivar differences have little effect (Rist et al., 1997). Increasing the mowing height of creeping bentgrass reduced ball roll and also increased turfgrass quality (Salaiz et al., 1995). Vertical shoot growth over the course of a day should reduce the extent of ball roll on a putting green surface (Throssell, 1981). Hardy and Rogers (1997) found that PGRs such as trinexapac-ethyl and flurprimidol $\{\alpha-(1-$ methylethyl $\alpha$-[4-(trifluoro-methoxy) phenyl]-5-pyrimidine-methanol $\}$ produced short-term increases in ball roll. However, the effects on either long-term or diurnal patterns of ball roll on creeping bentgrass putting greens have not been fully investigated, especially in climatic regions where summer stress can complicate management.

Therefore, the objectives of this research were to: 1) investigate the impact of monthly applications of trinexapac-ethyl and paclobutrazol on ball roll and turfgrass quality of 'Penncross' creeping bentgrass maintained at three different mowing heights; and 2) investigate the impact of the same PGRs on diurnal patterns of ball roll.

\section{Materials and Methods}

Expt. 1. Effects of mowing height and PGRs on ball roll and turfgrass quality over a 1-year period. This experiment was conducted from Apr. 1997 through Apr. 1998 at the North Carolina State Univ. Sandhills Research Station, Jackson Springs. Plant material was a 2-year-old stand of 'Penncross' creeping bentgrass growing on a Wakulla sand (sandy, siliceous, Thermic Psammentic Hapludults) with $94 \%$ sand, $4 \%$ silt, $2 \%$ clay, $2.4 \%$ organic matter, and a $\mathrm{pH}$ of 6.1 . The putting green was free of annual bluegrass contamination throughout the experiment. Plots were irrigated to prevent drought stress, and received total $\mathrm{N}$ fertilization of 294 
$\mathrm{kg} \cdot \mathrm{ha}^{-1}$ within peak periods of growth during the experiment, and biweekly applications of chlorothalonil (tetrachloroisophthalonitrile) during summer months for preventive disease control. The experimental design was a splitplot, with four PGR treatments and a nontreated control as subplots superimposed across each of three mowing heights $(4.8,4.0$, or $3.2 \mathrm{~mm})$. Each treatment combination was replicated four times.

Plots were mowed five times weekly at $0800 \mathrm{HR}$ using a walk-behind greens mower. Ball roll measurements were taken only on mowing days. Mowing treatments were initiated 16 Mar. 1997. PGRs were first applied 17 Apr. 1997 and included paclobutrazol $2 \mathrm{SC}$ at $0.14,0.28$, or $0.56 \mathrm{~kg} \cdot \mathrm{ha}^{-1}$ and trinexapac-ethyl $1 \mathrm{EC}$ at $0.05 \mathrm{~kg} \cdot \mathrm{ha}^{-1}$ (all concentrations expressed as a.i.). Treatments were applied to $1.53 \times 4.58-\mathrm{m}$ plots using a $\mathrm{CO}_{2}$-pressurized, hand-held, four-nozzle boom. Plot length was based upon expected requirements for full-size U.S. Golf Association (USGA, Far Hills, N.J.) Stimpmeter use (Gaussoin et al., 1995). Application pressure and carrier volume were $179 \mathrm{kPa}$ and 304 $\mathrm{L} \cdot \mathrm{ha}^{-1}$, respectively. Subsequent PGR treatments were applied every 4 weeks for a period of 1 year.

Ball roll and turfgrass quality data were recorded monthly from Apr. 1997 to Mar. 1998, the only exception being Jan. 1998. Turfgrass shoot density data were recorded from May 1997 to Apr. 1998. Ball roll was measured using a USGA Stimpmeter to provide consistency in measurement procedures. Stimpmeter measurements consisted of placing a golf ball in a notch on the upper surface of the instrument and slowly raising it until gravity released the ball down the shaft and onto the putting surface. Three measurements were made in each of two directions across each plot. Means of the six measurements were reported as the ball roll values for the plots. All data were recorded 4 to $5 \mathrm{~h}$ after plots were mowed to ensure the absence of any dew or other moisture that could have affected ball roll. Turfgrass quality was rated visually using a $1-9$ scale $(1=$ brown, low quality turf; $5=$ acceptable; $9=$ dark green, high quality turf). Turfgrass shoot density was also rated visually on a similar scale $(1=$ coarse, unplayable turf; $5=$ acceptable; $9=$ ideal dense turf).

Expt. 2. Effects of PGRs on diurnal changes in creeping bentgrass putting green speed. Three experiments were conducted during 1995 and 1996 to evaluate PGR effects on diurnal changes in ball roll for a 3-year-old 'Penncross' creeping bentgrass putting green at Prestonwood Country Club, Cary, N.C. The selected putting green for the experiments was grown in a rootzone that met USGA specifications for putting green construction (98\% sand, $0 \%$ silt, and $2 \%$ clay) and was free of annual bluegrass contamination. Throughout the three experiments at this site, the putting green was subjected to normal play conditions, and measurements were taken on days when the golf course was closed to play. The turf was mowed daily to a height of $4.0 \mathrm{~mm}$. Since the earliest measurements of ball roll in these experiments were taken at $0800 \mathrm{HR}$, a minimum of $1 \mathrm{~h}$ elapsed between mowing and data collection.

Each experiment included a nontreated control, trinexapac-ethyl at 0.025 or 0.05 $\mathrm{kg} \cdot \mathrm{ha}^{-1}$, and paclobutrazol at $0.28 \mathrm{~kg} \cdot \mathrm{ha}^{-1}$ with supplemental $\mathrm{N}$ at $12.2 \mathrm{~kg} \cdot \mathrm{ha}^{-1}$. Treatments were applied initially 6 Nov. 1995, 9 Apr. 1996, and 21 Oct. 1996, while repeat applications for the three respective experiments were made 4 Dec. 1995, 6 May 1996, and 19 Nov. 1996. All treatments were applied to $1.22 \times 3.66$-m plots using a $\mathrm{CO}_{2}$-pressurized, hand-held, four-nozzle boom at $179 \mathrm{kPa}$ of pressure delivering $304 \mathrm{~L} \cdot \mathrm{ha}^{-1}$. The experimental design for each experiment was a randomized complete-block with four replications.

Assessments of ball roll for experiments conducted during Fall 1995 and 1996 were made on 14 Dec. 1995 and 25 Nov. 1996, 10 and $6 \mathrm{~d}$ following the second PGR application, respectively. Measurements of ball roll were made at 0900, 1100, 1300, and $1500 \mathrm{HR}$ for each experiment. Ball roll for the experiment conducted in Spring 1996 was assessed both 4 and $17 \mathrm{~d}$ after the second PGR application. In this experiment, ball roll was measured at $0800,1000,1200,1400$, and $1600 \mathrm{HR}$. All data were recorded using a USGA Stimpmeter and were the compilation of three readings made in each of two directions.

Ball roll data for Expt. 1 were subjected to analysis of variance (ANOVA) for a splitplot design using SAS Version 6.12 (SAS Inst., Cary, N.C.). Main effects of mowing height and PGR treatments were analyzed, along with possible interactions between these variables. Standard F tests were used to determine significant $(P \leq 0.05)$ main effects and interactions, along with appropriate means separation for main effects using Fisher's Protected LSD test. Quality and shoot density data were analyzed in a similar fashion, the primary difference being greater appropriateness of $P$ values for such qualitative measurements. Data for the three individual experiments within Expt. 2 were subjected separately to ANOVA using SAS. Fisher's Protected LSD test was employed for mean separation when the ANOVA F test indicated significant differences at $P \leq 0.05$.

\section{Results and Discussion}

Expt. 1. Effects of mowing height and PGRs on ball roll and turfgrass quality over a 1-year period. Ball roll fluctuated seasonally, varying with the pattern of either shoot or root growth in cool-season turf (Table 1). The results support previous findings for seasonal ball roll fluctuation on creeping bentgrass putting greens in a more temperate climate (Rist et al., 1997). Main effects of mowing height were significant on all 11 assessment dates over the year (Table 1), with a steady increase in ball roll as mowing height was reduced, except for one date (14 October). This trend was consistent with previous reports (Salaiz et al., 1995). While ball roll increased progressively from July 1997 to Dec. 1997 on $4.8-\mathrm{mm}$ putting green plots, comparable increases in 3.2 and $4.0-\mathrm{mm}$ plots were not evident until November (Table 1). These observations may relate to reduced levels of summer stress associated with higher mowing heights (Mazur, 1986). Monthly increases in ball roll were also observed, at all mowing heights, from April to May, but were more rapid than those observed in the fall (Table 1). Ball roll decreased from May to June at all mowing heights, but showed inconsistent patterns across mowing heights through the rest of the summer.

Main effects of PGRs were significant from June through Sept. 1997, and again in Mar. 1998 (Table 1). Paclobutrazol, at either 0.28 or $0.56 \mathrm{~kg} \cdot \mathrm{ha}^{-1}$, reduced ball roll from June through Sept. 1997, as compared with nontreated plots or, in all but one case, plots treated with trinexapac-ethyl (Table 1). No PGR treatment reduced ball roll in Mar. 1998, but paclobutrazol at $0.14 \mathrm{~kg} \cdot \mathrm{ha}^{-1}$ increased it (Table 1). Trinexapac-ethyl also reduced ball roll from June through August (Table 1), but was less effective than the higher concentrations of paclobutrazol. Because ball roll measurements were always taken 1 month after PGR application, possible short-term effects may have gone unnoticed (Hardy and Rogers, 1997). Our results indicate that, for creeping bentgrass putting greens, PGRs may have a detrimental effect on ball roll, especially during the hot summer months. Thus, PGRs do not appear to be suitable agents for longterm increases in ball roll on creeping bentgrass putting greens in the transition zone and therefore are unable to mimic changes in cultural practices such as mowing height.

Mowing height significantly affected turfgrass quality in 7 of 11 months (Table 2). In all cases, significance was attributable to reduced quality in plots maintained at 3.2 $\mathrm{mm}$; plots mowed at either 4.0 or $4.8 \mathrm{~mm}$ were of comparable quality throughout the experiment (Table 2). Results were consistent with those of Salaiz et al. (1995)

Treatment with PGRs significantly affected turfgrass quality in 7 of 11 months (Table 2). Trinexapac-ethyl either had no effect on, or improved, turfgrass quality, regardless of date of evaluation. Paclobutrazol, especially when applied at either 0.28 or 0.56 $\mathrm{kg} \cdot \mathrm{ha}^{-1}$, had either no effect on or improved turfgrass quality from May through July (Table 2). From August until the end of the experiment, it reduced visual quality. Averaged across PGR treatments, quality was acceptable (rating value $>5$ ) regardless of mowing height, although $3.2-\mathrm{mm}$ putting greens most closely approached this level (Table 2). Paclobutrazol at $0.56 \mathrm{~kg} \cdot \mathrm{ha}^{-1}$ was the only PGR treatment that resulted in unacceptable quality.

Turfgrass shoot density, as an important component of visual quality, was also dependent on mowing height. However, while overall seasonal patterns paralleled those for turfgrass quality, the effects of mowing height differed. Shoot density was highest in turf mowed at $3.2 \mathrm{~mm}$ in 5 of the 8 months during 
Table 1. Main effects of putting green mowing height and plant growth regulator (PGR) application on ball roll over a 1-year period.

\begin{tabular}{|c|c|c|c|c|c|c|c|c|c|c|c|}
\hline \multirow[b]{3}{*}{ Treatment } & \multicolumn{11}{|c|}{ Ball roll $(\mathrm{cm})^{\mathrm{z}}$} \\
\hline & \multicolumn{9}{|c|}{1997} & \multicolumn{2}{|c|}{1998} \\
\hline & 17 Apr. $^{y}$ & 14 May & 11 June & 9 July & 6 Aug. & 2 Sept. & 14 Oct. & 12 Nov. & $11 \mathrm{Dec}$. & 6 Feb. & 27 Mar. \\
\hline \multicolumn{12}{|c|}{ Mowing ht $(\mathrm{mm})$} \\
\hline 3.2 & $266 c^{x}$ & $296 \mathrm{c}$ & $285 \mathrm{c}$ & $300 \mathrm{c}$ & $295 \mathrm{c}$ & $287 \mathrm{c}$ & $300 \mathrm{c}$ & $310 \mathrm{c}$ & $311 \mathrm{c}$ & $280 \mathrm{c}$ & $276 \mathrm{c}$ \\
\hline 4.0 & $240 \mathrm{~b}$ & $264 \mathrm{~b}$ & $255 \mathrm{~b}$ & $255 \mathrm{~b}$ & $254 \mathrm{~b}$ & $252 \mathrm{~b}$ & $244 \mathrm{a}$ & $291 \mathrm{~b}$ & $291 \mathrm{~b}$ & $274 \mathrm{~b}$ & $244 \mathrm{~b}$ \\
\hline 4.8 & $219 \mathrm{a}$ & $243 \mathrm{a}$ & $221 \mathrm{a}$ & $216 \mathrm{a}$ & $228 \mathrm{a}$ & $234 \mathrm{a}$ & $262 \mathrm{~b}$ & $268 \mathrm{a}$ & $270 \mathrm{a}$ & $248 \mathrm{a}$ & $199 \mathrm{a}$ \\
\hline \multicolumn{12}{|c|}{$P G R$ treatment $\left(\mathrm{kg} \cdot h a^{-1}\right)^{w}$} \\
\hline Nontreated & $245 \mathrm{a}$ & $270 \mathrm{a}$ & $265 \mathrm{c}$ & $265 \mathrm{c}$ & $269 \mathrm{c}$ & $267 \mathrm{~b}$ & $262 \mathrm{a}$ & $291 \mathrm{a}$ & $286 a$ & $265 \mathrm{a}$ & $237 \mathrm{a}$ \\
\hline $\mathrm{PB}, 0.14$ & $243 \mathrm{a}$ & $267 \mathrm{a}$ & $259 \mathrm{bc}$ & $258 \mathrm{~b}$ & $261 \mathrm{~b}$ & $260 \mathrm{~b}$ & $276 \mathrm{a}$ & $291 \mathrm{a}$ & $293 a$ & $269 \mathrm{a}$ & $248 \mathrm{~b}$ \\
\hline $\mathrm{PB}, 0.28$ & $238 \mathrm{a}$ & $263 \mathrm{a}$ & $246 \mathrm{a}$ & $251 \mathrm{a}$ & $251 \mathrm{a}$ & $247 \mathrm{a}$ & $271 \mathrm{a}$ & $287 \mathrm{a}$ & $290 \mathrm{a}$ & $264 \mathrm{a}$ & $232 \mathrm{a}$ \\
\hline $\mathrm{PB}, 0.56$ & $239 a$ & $265 \mathrm{a}$ & $243 \mathrm{a}$ & $252 \mathrm{ab}$ & $251 \mathrm{a}$ & $248 \mathrm{a}$ & $269 \mathrm{a}$ & $286 \mathrm{a}$ & $295 \mathrm{a}$ & $275 \mathrm{a}$ & $244 \mathrm{ab}$ \\
\hline TE, 0.05 & $243 a$ & $275 \mathrm{a}$ & $256 \mathrm{~b}$ & $258 \mathrm{~b}$ & $262 \mathrm{~b}$ & $266 \mathrm{~b}$ & $265 \mathrm{a}$ & $294 \mathrm{a}$ & $290 a$ & $263 \mathrm{a}$ & $239 a$ \\
\hline
\end{tabular}

${ }^{2}$ Means of six measurements, three in each of two directions.

y Dates of ball roll measurement coincided with dates of PGR applications.

'Mean separation within columns and factors (mowing height, PGR treatment) by Fisher's LSD Test $(\alpha=0.05)$.

${ }^{\mathrm{w}} \mathrm{PB}=$ paclobutrazol; $\mathrm{TE}=$ trinexapac-ethyl.

Table 2. Main effects of mowing height and plant growth regulators (PGRs) on creeping bentgrass putting green quality over a 1-year period.

\begin{tabular}{|c|c|c|c|c|c|c|c|c|c|c|c|}
\hline \multirow[b]{3}{*}{ Treatment } & \multicolumn{11}{|c|}{ Turfgrass visual quality $^{z}$} \\
\hline & \multicolumn{9}{|c|}{1997} & \multicolumn{2}{|c|}{1998} \\
\hline & 17 Apr. & 14 May & 11 June & 9 July & 6 Aug. & 2 Sept. & 14 Oct. & 12 Nov. & $11 \mathrm{Dec}$. & 6 Feb. & 27 Mar. \\
\hline \multicolumn{12}{|c|}{ Mowing ht (mm) } \\
\hline 3.2 & 6.4 & 6.6 & 6.1 & 6.1 & 6.0 & 6.0 & 5.9 & 6.0 & 5.9 & 5.4 & 5.9 \\
\hline 4.0 & 7.1 & 7.2 & 6.9 & 6.8 & 6.8 & 6.9 & 6.6 & 6.5 & 6.1 & 6.0 & 6.3 \\
\hline 4.8 & 6.8 & 7.2 & 6.9 & 6.4 & 6.8 & 6.8 & 6.8 & 6.6 & 6.2 & 6.0 & 6.7 \\
\hline$P>\mathrm{F}^{\mathrm{y}}$ & 0.0001 & NS & 0.0086 & 0.0002 & 0.0001 & NS & 0.0189 & 0.0016 & NS & NS & 0.0187 \\
\hline \multicolumn{12}{|c|}{ PGR treatment $\left(\mathrm{kg} \cdot \mathrm{ha^{-1 }}\right)^{x}$} \\
\hline Nontreated & 6.8 & 6.8 & 6.4 & 6.4 & 6.6 & 6.6 & 6.6 & 6.8 & 6.3 & 6.4 & 6.6 \\
\hline $\mathrm{PB}, 0.14$ & 6.8 & 6.8 & 6.7 & 6.5 & 6.5 & 6.4 & 6.4 & 6.3 & 6.2 & 6.0 & 6.3 \\
\hline $\mathrm{PB}, 0.28$ & 6.8 & 7.1 & 6.8 & 6.5 & 6.5 & 6.7 & 6.5 & 6.3 & 5.9 & 5.4 & 6.3 \\
\hline $\mathrm{PB}, 0.56$ & 6.8 & 7.4 & 6.8 & 6.4 & 6.5 & 6.5 & 6.2 & 5.8 & 5.6 & 4.7 & 5.7 \\
\hline TE, 0.05 & 6.8 & 6.9 & 6.6 & 6.7 & 6.7 & 6.7 & 6.5 & 6.7 & 6.5 & 6.4 & 6.5 \\
\hline$P>\mathrm{F}^{\mathrm{y}}$ & NS & 0.0001 & 0.0001 & 0.0008 & 0.0001 & 0.0001 & NS & 0.0001 & 0.0001 & NS & NS \\
\hline
\end{tabular}

${ }^{\mathrm{z} B a s e d}$ on a 1-9 scale: (1 = completely desiccated turf, $5=$ minimally acceptable, $9=$ ideal turf).

${ }^{\mathrm{y}} \mathrm{F}$ tests for each date test hypotheses that mowing height or PGR treatments, averaged across the other experimental variable, had no effect on turfgrass visual quality. Two significant interractions existed between plant growth regulator and mowing height, in May 1997 and Aug. 1997.

${ }^{x} \mathrm{~PB}=$ paclobutrazol; $\mathrm{TE}=$ trinexapac-ethyl.

${ }^{\text {Ns Nonsignificant. }}$

which mowing height affected it (Table 3). By contrast, overall visual quality was not enhanced when turf was mowed at $3.2 \mathrm{~mm}$ (Table 2). Shoot density was reduced in areas maintained at $3.2 \mathrm{~mm}$ from August through October, suggesting that summer stress affected vigor (Table 3 ). While quality was unaffected or reduced at the 3.2-mm mowing height, the general increases in shoot density highlight the influence of other parameters, such as color or uniformity, on visual quality ratings.

Treatment with PGRs significantly affected turfgrass shoot density in 4 of 11 months (Table 3). Trinexapac-ethyl had negligible effects but paclobutrazol tended to reduce shoot density during the 4 months that PGRs were effective (Table 3). No PGR treatment resulted in unacceptable shoot density. Both the subtlety of PGR effects on shoot density and the lack of a clear relationship between PGR effects on visual quality and shoot density suggest that other visual parameters influence the perception of overall quality.

Three significant interactions between mowing height and PGR treatments, as pertains to turfgrass quality or shoot density, occurred during the course of this experiment in May 1997 and Aug. 1997 or Nov. 1997, respectively. The interaction in May ( $P=$ 0.0330 ) was attributable to enhancement of quality by trinexapac-ethyl in plots mowed at $4.0 \mathrm{~mm}$ but not in those mowed at either 3.2 or $4.8 \mathrm{~mm}$. The interaction in August $(P=$ 0.0052 ) was attributable to paclobutrazol, applied at 0.28 or $0.56 \mathrm{~kg} \cdot \mathrm{ha}^{-1}$, enhancing quality in plots mowed at $3.2 \mathrm{~mm}$, but reducing it at the other two mowing heights. In November $(P=0.0015)$, shoot density was enhanced by paclobutrazol at 0.28 or 0.56 $\mathrm{kg} \cdot \mathrm{ha}^{-1}$ in areas maintained at $3.2 \mathrm{~mm}$ but not in those maintained at either 4.0 or $4.8 \mathrm{~mm}$.

The mowing height data suggest that, while the shortest mowing height of $3.2 \mathrm{~mm}$ consistently enhanced ball roll, compromises in turfgrass quality and shoot density during stressful summer periods make $3.2 \mathrm{~mm}$ risky during this time of the year. We therefore suggest that, based on our data for ball roll, turfgrass quality, and turfgrass shoot density, a $4.0-\mathrm{mm}$ mowing height may provide an ideal mix of adequate ball roll and consistent seasonal turfgrass quality in southern or transition zone areas of creeping bentgrass putting green management.

The PGR data suggest that continuous use of paclobutrazol on creeping bentgrass putting greens must be approached with caution, especially at high application rates designed to suppress annual bluegrass. However, the cost of such caution may be reduced efficacy of annual bluegrass control programs. Paclobutrazol use may therefore preclude possible compromises in ball roll, turfgrass quality, or shoot density.

Expt. 2. Effects of PGRs on diurnal changes in creeping bentgrass putting green speed. Ball roll was enhanced by PGR treatments at both 0900 and 1500 HR in Fall 1995 (Table 4) and at 1100, 1300, and $1500 \mathrm{HR}$ in Fall 1996. Trinexapac-ethyl, at $0.05 \mathrm{~kg} \cdot \mathrm{ha}^{-1}$ was the most consistent treatment in either of the two experiments. However, trinexapacethyl at $0.025 \mathrm{~kg} \cdot \mathrm{ha}^{-1}$ and paclobutrazol at $0.28 \mathrm{~kg} \cdot \mathrm{ha}^{-1}$ were also effective on several occasions (Table 4). Patterns of ball roll in Spring 1996 again showed trinexapac-ethyl at $0.05 \mathrm{~kg} \cdot \mathrm{ha}^{-1}$ to be the most effective treatment in increasing diurnal ball roll, particularly $4 \mathrm{~d}$ after the sequential application of PGRs (Table 4). However, trinexapac-ethyl at $0.025 \mathrm{~kg} \cdot \mathrm{ha}^{-1}$ and paclobutrazol at 0.28 $\mathrm{kg} \cdot \mathrm{ha}^{-1}$ were less effective in spring than in fall. Paclobutrazol actually reduced ball roll at four separate rating times over the two diurnal periods (Table 4). This again suggests caution with paclobutrazol use and 
TuRf MANAgement

Table 3. Main effects of mowing height and plant growth regulators (PGRs) on creeping bentgrass putting green shoot density over a 1-year period.

\begin{tabular}{|c|c|c|c|c|c|c|c|c|c|c|c|}
\hline \multirow[b]{3}{*}{ Treatment } & \multicolumn{10}{|c|}{ Turfgrass shoot density ${ }^{z}$} & \\
\hline & \multicolumn{8}{|c|}{1997} & \multicolumn{3}{|c|}{1998} \\
\hline & 8 May & 11 June & 9 July & 6 Aug. & 2 Sept. & 14 Oct. & 12 Nov. & $11 \mathrm{Dec}$. & 6 Feb. & 12 Mar. & 8 Apr. \\
\hline \multicolumn{12}{|c|}{ Mowing ht (mm) } \\
\hline 3.2 & 7.0 & 7.5 & 6.8 & 5.0 & 6.0 & 6.4 & 6.7 & 6.8 & 6.6 & 6.7 & 6.9 \\
\hline 4.0 & 6.9 & 7.0 & 6.7 & 6.6 & 6.7 & 6.6 & 6.6 & 6.6 & 6.5 & 6.5 & 6.7 \\
\hline 4.8 & 6.5 & 6.5 & 6.6 & 6.6 & 6.7 & 6.7 & 6.6 & 6.5 & 6.6 & 6.5 & 6.5 \\
\hline$P>\mathrm{F}^{\mathrm{y}}$ & 0.0001 & 0.0001 & NS & 0.0001 & 0.0001 & 0.0012 & NS & 0.0001 & NS & 0.0001 & 0.0001 \\
\hline \multicolumn{12}{|c|}{$P G R$ treatment $\left(\mathrm{kg} \cdot \mathrm{ha^{-1 }}\right)^{\mathrm{x}}$} \\
\hline Nontreated & 6.8 & 7.0 & 6.6 & 6.0 & 6.4 & 6.5 & 6.6 & 6.6 & 6.6 & 6.6 & 6.8 \\
\hline $\mathrm{PB}, 0.14$ & 6.8 & 7.0 & 6.7 & 6.0 & 6.4 & 6.5 & 6.5 & 6.6 & 6.5 & 6.6 & 6.7 \\
\hline $\mathrm{PB}, 0.28$ & 6.8 & 7.0 & 6.8 & 6.3 & 6.5 & 6.6 & 6.7 & 6.7 & 6.5 & 6.6 & 6.7 \\
\hline $\mathrm{PB}, 0.56$ & 6.8 & 7.1 & 6.8 & 6.0 & 6.4 & 6.6 & 6.7 & 6.6 & 6.5 & 6.5 & 6.6 \\
\hline $\mathrm{TE}, 0.05$ & 6.8 & 7.0 & 6.7 & 6.0 & 6.5 & 6.5 & 6.6 & 6.6 & 6.7 & 6.6 & 6.8 \\
\hline PGR Trt. $P>\mathrm{F}^{\mathrm{y}}$ & NS & NS & NS & NS & NS & NS & 0.0445 & NS & 0.0407 & 0.0219 & 0.0031 \\
\hline
\end{tabular}

${ }^{\mathrm{z}}$ Based on a 1-9 scale: $(1=$ completely coarse and unplayable turf; $5=$ minimally acceptable; $9=$ ideal dense turf).

${ }^{\mathrm{y}} \mathrm{F}$ tests for each date test hypotheses that mowing height or PGR treatments, averaged across the other experimental variable, had no effect on shoot density. A significant interaction existed between plant growth regulator and mowing height in Nov. 1997.

${ }^{x} \mathrm{~PB}=$ paclobutrazol; $\mathrm{TE}=$ trinexapac-ethyl

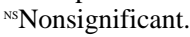

Table 4. Effects of PGRs on diurnal measurements of ball roll on a creeping bentgrass putting green in Fall 1995, Fall 1996, and Spring 1996.

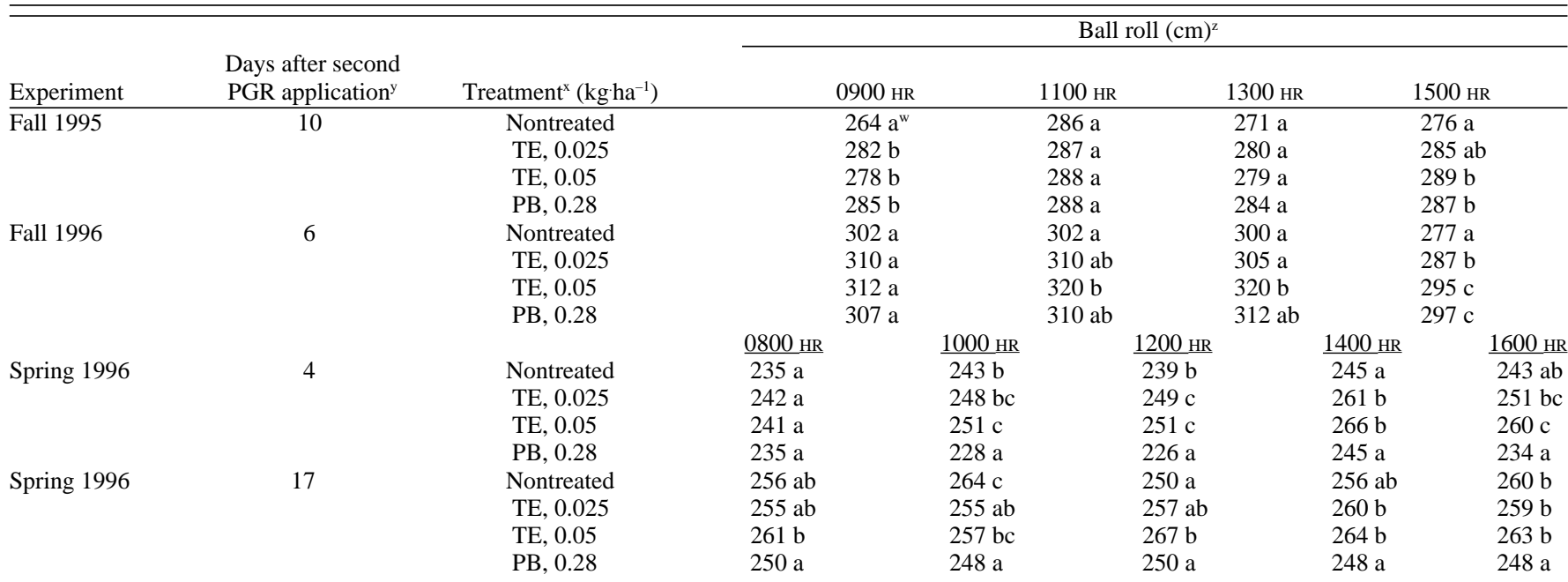

${ }^{2}$ Ball roll data are means of six measurements, three each in two directions.

'Treatment timings: Fall 1995—6 Nov. 1995 and 4 Dec. 1995; Fall 1996-21 Oct. 1996 and 19 Nov. 1996; Spring 1996 -9 Apr. 1996 and 6 May 1996.

${ }^{x} \mathrm{TE}=$ trinexapac-ethyl $1 \mathrm{EC}, \mathrm{PB}=$ paclobutrazol $2 \mathrm{SC}$ with $\mathrm{N}$ at $12.2 \mathrm{~kg} \cdot \mathrm{ha}^{-1}$.

${ }^{w}$ Mean separation within columns and experiments by Fisher's LSD test $(\alpha=0.05)$.

support our observations on several rating dates in Expt. 1.

Experiments conducted in Fall 1995 and 1996 both demonstrated that PGRs may have a positive effect on diurnal patterns of ball roll. Comparable results were obtained with a similar experiment conducted in Spring 1996. Short-term increases in ball roll have previously been reported with PGRs but were amplified by rolling the putting green (Hardy and Rogers, 1997). Among the three experiments, only in the Fall 1996 experiment did ball roll decline in nontreated plots over the course of the day (Table 4). Significantly higher ball roll in PGR-treated plots could therefore indicate that PGRs enhance ball roll rather than simply making it more consistent.

Turfgrass quality in plots treated with trinexapac-ethyl at $0.05 \mathrm{~kg} \cdot \mathrm{ha}^{-1}$ was reduced in Fall 1995 on the day ball roll measurements were made, while an increase in turfgrass quality was observed in plots treated with paclobutrazol (data not presented). The increase in quality observed with the latter was presumably due to the application of $\mathrm{N}$ at $12.2 \mathrm{~kg} \cdot \mathrm{ha}^{-1}$ each time paclobutrazol was applied. Assessment of turfgrass quality in either Fall or Spring 1996 showed similar patterns.

Overall, PGR effects on ball roll may be positive over the course of any given day. However, in the long term, ball roll does not seem to benefit from applications of PGRs, and, if anything, is negatively affected. Mowing height effects on both ball roll and turfgrass visual quality in Expt. 1 were much more dramatic and consistent than were PGR effects. Negative effects on ball roll were confined to applications of paclobutrazol, perhaps because this PGR reduced visual quality and shoot density. Trinexapac-ethyl had minimal to positive effects on either ball roll or turfgrass quality. It is therefore speculated that longer periods of activity in soil and the less specialized mode of action for paclobutrazol may make it a more aggressive growth inhibiting agent, especially when applied continuously, than is trinexapac-ethyl. However, the lack of trinexapac-ethyl activity on annual bluegrass limits its suitability as a possible alternative to paclobutrazol in areas where bluegrass control programs are common (Johnson and Murphy, 1996). We suggest that the reduction in ball roll associated with increasing mowing height from 3.2 to $4.0 \mathrm{~mm}$ is compensated for by better turfgrass visual quality and/or shoot density during stressful summer periods.

\section{Literature Cited}

Burpee, L.L., D.E. Green, and S.L. Stephens. 1996. Interactive effects of plant growth regulators and fungicides on epidemics of dollar spot in creeping bentgrass. Plant Dis. 80:1245-1250.

Callahan, L.M. 1978. Bentgrass performance trials for golf greens in Tennessee. Tenn. Farm Home Sci. Prog. Rpt. 105:24-26.

Fagerness, M.J. and D. Penner. 1998a. Spray 
application parameters that influence the growth inhibiting effects of trinexapac-ethyl. Crop Sci. 38:1023-1027.

Fagerness, M.J. and D. Penner. 1998b. Evaluation of V-10029 and trinexapac-ethyl for annual bluegrass seedhead suppression and growth inhibition in five cool-season species. Weed Technol. 12:436-440.

Gaussoin, R.E., J.L. Nus, and L. Leuthold. 1995. A modified Stimpmeter for small plot turfgrass research. HortScience 30:547-548.

Hardy, J.A. and J.N. Rogers, III. 1997. Effects of PGRs and rolling on three putting green construction methods. Agron. Abstr. 89:125-126.
Johnson, B.J. 1989. Response of tall fescue (Festuca arundinacea) to plant growth regulator application dates. Weed Technol. 3:408-413.

Johnson, B.J. and R.N. Carrow. 1989. Bermudagrass encroachment into creeping bentgrass as affected by herbicides and plant growth regulators. Crop Sci. 29:1220-1227.

Johnson, B.J. and T.R. Murphy. 1996. Suppression of a perennial subspecies of annual bluegrass (Poa annua ssp. reptans) in a creeping bentgrass (Agrostis stolonifera) green with plant growth regulators. Weed Technol. 10:705-709.

Mazur, A.R. 1986. Bentgrass management in the hot humid Southeast. Fla. Turf Digest 3:20-22.
Rist, A.M., R.E. Gaussoin, R.C. Shearman, J.D. Fry, and W.W. Stroup. 1997. Season and genotype influence golf ball roll distance on creeping bentgrass. HortScience 32:878-879.

Salaiz, T.A., G.L. Horst, and R.C. Shearman. 1995. Mowing height and vertical mowing frequency effects on putting green quality. Crop Sci. 35:1422-1425.

Throssell, C.S. 1981. Management factors affecting putting green speed. MS Thesis, Pennsylvania State Univ., University Park.

Watschke, T.L. and J.M. DiPaola. 1995. Plant growth regulators. Golf Course Mgt. 64:5962. 